\title{
ETHICS, ECONOMIC ADVICE, AND ECONOMIC POLICY
}

\author{
JOSEPH E. STIGLITZ
}

\section{INTRODUCTION}

IN this chapter I wish to discuss the ethical dimensions of a variety of issues in development and international economics that I confronted as a member and chairman of the Council of Economic Advisers under President Clinton and as chief economist of the World Bank., Economists have long bought into the importance of self-interest not only in explaining behavior, but also in yielding efficient outcomes. But economists have also long been aware of the limitations of these perspectives. Not only does the self-interest/market paradigm often fail to generate efficient outcomes, but even when it does, these outcomes may not comport with notions of social justice. Still, in the realm of economic policy, governments typically justify foreign aid and other policies aimed at poorer countries in terms of their own self-interest: how such policies increase world incomes, thereby increasing the country's own exports, or contribute to global political stability, from which all benefit. Such arguments deflect attention from the moral justification for these policies.

Ethics in the relationship between developed and less developed countries dictate that the developed countries treat the less developed countries fairly, aware of their

1 The author is University Professor at Columbia University. He previously served as senior vice president and chief economist of the World Bank and as Chairman of the US Council of Economic Advisers under President Clinton.

2 This paper was prepared for the Inter-American Initiative on Social Capital, Ethics and

Development, December 2002; earlier versions were presented in 2000 at a meeting in Milan sponsored by the Vatican in connection with the Jubilee, and at a conference at the Interamerican Development Bank in Washington, DC. The content has not been significantly updated since the original drafting. Before publication in 2013, I inserted an occasional footnote or parenthetical remark on how matters have evolved since then. 
disadvantaged economic position, and acknowledging that taking advantage of one's own economic power will inevitably hurt the poor within developing countries. We have seen several instances where, in global economic relationships, this precept has been grossly violated: an international trade agenda set to advance the interests of the more developed countries, at least partially at the expense of the less developed-so much so that on average the world's poorest region was actually worse off at the end of the last round of trade negotiations; and an international environmental agreement that provided that those rich countries that today are polluting more be entitled to continue polluting more into the future. ${ }^{3}$

There are other dimensions to globalization that illustrate the same violation of basic ethical precepts. Consider the argument made for free capital mobility: it increases world efficiency. Never mind the devastation that it might bring to small, poor countries-and the poor within those countries--that are not able to withstand the seemingly irrational vicissitudes of investor sentiments and the consequent reversals of capital flows! But globalization in these factor movements is much like globalization in trade: there we saw the powerful tell the less developed countries to open their markets to the goods of the more industrial countries, while keeping their own markets closed. The factor that the developed countries export is capital, while the factor that the developing countries have in abundance is labor. From an economic perspective, global efficiency can be attained by free mobility of labor every bit as well as it can be attained through free mobility of capital. But the developed countries are not arguing that there should be free mobility of labor. They are not offering to open up their doors to the poor of the world. The reason is obvious: they are aware of the social dislocation-and the consequent political pressure-- that such migration would bring about. But they simply cannot put themselves in the shoes of the developing countries. And they are unsympathetic when the developing countries raise precisely the same objections to opening up their countries to the factors and goods that are in abundance in the developed world. ${ }^{4}$

I shall conduct my discussion at the level of pragmatic ethics, that is, I shall not try to derive the ethical principles from first-order considerations. Rather, I shall explore the implications of certain widely held ethical precepts for the conduct of international economic relations and, by extension, the conduct of development and other economists who operate in this environment. By the same token, I shall evaluate certain actions,

${ }^{3}$ In the case of international trade agreements, there was the hope that the round of negotiations begun in November, 2001 at Doha would rectify the imbalances of earlier trade agreements; it was even called the development round. But in the more than a decade since the inauguration of this round, the developed countries reneged, so much so that the round no longer deserves that epithet. Indeed, some of the bilateral and so-called "partnership" agreements have been as or even more unbalanced than the agreements of the past. So, too, there was hope for a global agreement affecting climate change in which the developed countries lived up to their moral responsibilities. But this has not been forthcoming, either.

${ }^{4}$ Interestingly, more than a decade after the IMF attempted, in Hong Kong in 1997 , to change its charter to enable it to force countries to liberalize their capital markets, the Fund recognized that capital market restrictions can be an important tool for countries to help stabilize their economy. 
ascertaining which can be viewed as principled actions. I shall not undertake the far more ambitious goal of defining a set of principles for action, though to be sure, my remarks are intended as a prelude to that task. I will use this occasion to raise questions as much as provide answers. ${ }^{5}$

I focus on five concepts in particular: honesty, fairness, social justice (including a concern for the poor), externalities, and responsibility. Although the meaning of most of these terms should be self-evident, let me briefly comment on each. Honesty goes beyond the dictate to refrain from outright lying; it comes closer to the dictum of telling the truth, the whole truth, and nothing but the truth. Misrepresentation-asserting that there is evidence for some proposition when there is none-violates the principle of honesty. ${ }^{6}$ Fairness includes what economists call horizontal equity-either treating everyone the same (e.g., not discriminating on the basis of race or gender), or, to the extent that it is desirable to treat those in different circumstances differently (e.g., the aged and the handicapped may need special treatment), treating those in similar positions similarly. The hard question, of course, is, What are meaningful differences, differences that could justify differences in treatment? Favoritism--including giving special treatment to special interests-is thus a violation of the ethical norm of fairness. Social justice includes helping those in need, and doing so in ways that enhance their sense of dignity and the ability to assume individual responsibility for themselves. "Externalities" entail that individuals should not impose costs on others. Littering is, in this view, "wrong", a violation of an ethical norm. Responsibility is the ethical norm that individuals should take responsibility for their own actions and for the consequences of those actions.

Ethical issues arise in every aspect of economics and economic policymaking. We recognize, for instance, the ethical problems posed by conflict of interest; and that the multitude of positions that individuals have also makes such conflict of interest inevitable. Today, modern ethical norms require disclosure of significant conflict of interest, reflecting the precept of honesty. It is not commonly viewed to be immoral to take actions, in the role of a fiduciary, or to provide advice, from which one might oneself benefit. But it is immoral not to disclose the conflict of interest, so that those affected

\footnotetext{
5 Much of what I have to say could be justified in terms of more general principles, for example, Kant's categorical imperative, or the Rawisian analysis of social justice. The latter may be particularly useful in approaching the issues of equity discussed below: What kind of international social and economic order would one want behind the veil of ignorance, not knowing whether one would be born in a developed or developing country? Toward the end of this chapter, I shall try to put some of the ethical precepts into a broader context: the rules and norms that facilitate cooperative social interactions.

${ }^{6}$ Honesty is a precept that can be taken as a value on its own, or as instrumental: actions taken on the basis of distorted information may lead to adverse results. Presumably, one of the reasons for dishonesty is to induce others to take actions that, were they to know the truth, they would not. Thus, not disclosing fully the risks of capital market liberalization-and purporting that there are gains from such liberalization when there is little evidence that there are such gains-may induce countries to liberalize when, were they provided with more accurate information, they would not. Even if the country would have, in any case, liberalized its capital markets, the distorted information may lead it not to provide the safety net that it would have provided, were it fully aware of the risks.
} 
can take appropriate precautions. The modern theory of agency recognizes that agents do not in general adopt the interests of those (the principal) whom they are supposed to be serving as their own; it is the responsibility of the principal to design incentive structures that align those interests, as much as possible. But it is wrong for the agent, for instance, to steal, to accept kickbacks from clients, or to engage in a host of other corrupt practices.

Advisors face ethical issues. Government bureaucrats and elected officials face ethical issues, such as those associated with corruption. Governments face ethical issues in the design of programs; and international institutions face ethical issues. I begin this chapter by subjecting the role of economic advisor to ethical analysis: What does it mean to be an ethical economic advisor? The question is an important one, because the interna tional financial institutions are actively involved in providing economic advice. In doing so, do they behave ethically? I then examine specific issues: ethics in the treatment of developing countries by developed countries, for example, ethics in the areas of trade, global environmental policies, debt forgiveness, growth strategies, crisis management; and finally, ethical issues in population policy.

\section{The Ethics of the Economic Advisor}

Most professions have clear ethical principles. In medicine, these are embedded in the Hippocratic Oath, which includes doing no harm. In a sense, the ethical norms seek to mitigate the adverse consequences of the unbridled pursuit of self-interest, in particular those that arise whenever there are agency problems (where, because of lack of information, one party can take advantage of another). Violating these ethical principles harms the entire profession (there is, in this sense, an externality). It destroys trust. It is, for instance, unethical for a doctor to prescribe a medicine because he receives a kickback from the manufacturer. The patient, not knowing the reason a doctor prescribes a particular medicine over another, assumes the doctor is prescribing the medicine in the best interest of the patient. Thus, actions that could lead to a conflict of interest between the professional and the person for whom he or she is providing a service are unethical Since a central part of the service being provided by most professions is information, honesty is a critical virtue.

There is a large economic cost to the destruction of trust. In simplistic models, individual self-interest leads to efficient outcomes; individuals act, and are expected to act, in their self-interest. But in modern theories in which information imperfections and incomplete markets play an important role, self-interested behavior in general does not yield efficient outcomes. Equilibria based on trust can yield better outcomes than those in which trust is absent. The patient, for instance, will be induced to get second and third opinions, because he will doubt the disinterested nature of the doctor's advice, if he believes that the doctor has a large financial stake in that advice. There is thus an instrumental argument for ethical behavior. 
Some principles governing the behavior of economic advisors are straightforward. Clearly, there is an ethical mandate not to take advantage of inside information obtained as an advisor for profit, or to directly use connections generated in an advisory role for profit. ${ }^{7}$ Furthermore, there are ethical (and often legal) norms for disclosure. Transparency mitigates, but does not totally eliminate, the danger that advice would be driven by self-interest. A consultant to a firm that had a short position in the stock of the firm would have an incentive to provide advice that would lead to the decrease in the market value of the firm. Few firms would allow the consultant to maintain such a position were they to know about it. Similarly, a consultant hired to advise a firm on the choice of a supplier should not have a financial interest in one of the suppliers, and if he does, he should disclose it; to not do so would be unethical.

But there are less straightforward implications as well, and it is these to which I want to call attention. First, honesty requires full disclosure of the limits of knowledge. Indeed, this has become an explicit part of the norms of good science. In the hard sciences one always presents the range of estimates, the confidence intervals with which certain results are held. The recognition of these uncertainties is even more important in the social sciences. Different propositions are held with different degrees of confidence. For instance, economists can claim with considerable certainty that hyperinflation has adverse effects on the economy. We can claim with some confidence that capital market liberalization is associated with greater risks, particularly for small, open, developing economies. On the other hand, honesty would dictate that an advisor recommending capital market liberalization reveals the absence of empirical evidence proving that capital market liberalization leads to faster growth (or at least after any supposed evidence is ambiguous and weak), and that economic theories supporting capital market liberalization are disputed. He would qualify any argument that capital account liberalization is helpful in inducing foreign direct investment by pointing out that the developing country that has been most successful in recruiting foreign direct investment-China-has not liberalized its capital account.

Second, honesty requires revealing that there is more than one Pareto-efficient policy. There are tradeoffs, with different policies affecting different groups differently, imposing different risks on different segments of society. Economic advice should focus on ensuring the efficiency of policies (to put it technically, to ensure that the economy is on the Pareto frontier), but it is the responsibility of political processes to choose the points on the Pareto frontier. When an economist recommends a particular point on the frontier as if it were the only efficient policy, he is using the cover of his supposed economic expertise to advance a political position. This is a misrepresentation. It becomes

7 The most famous instance in recent years of an alleged violation of this ethical norm was in Russia, where two of the American advisors were accused of using their inside connections to obtain licenses for friends to establish funds. (Subsequent to the publication of the original version of this chapter, an in-depth of analysis of these events was provided by David McClintick, and severe penalties were imposed on Harvard University and Andrei Shleifer.) See McClintick, David. 2006. "How Harvard Lost Russia." Institutional Investor, January. 
a particularly serious misrepresentation when the advisor, or interests with which he is affiliated, might be expected to benefit disproportionately from the particular policies being pursued. For instance, if there are a range of policies, some of which are more advantageous to those in the financial market, it would be unethical for an advisor representing financial interests not to disclose the fact that the particular policy he advocates would be particular advantageous to those groups. ${ }^{8}$

But in the public sphere today, there is a problem of "revolving doors," which are a manifestation of exactly these kinds of ethical conflicts. Individuals have what might be viewed as a contingent interest. Those who serve special interests well while in public service often get rewarded with lucrative positions after public service. Many governments are aware of the conflict of interest to which this gives rise. To mitigate the inevitable, related ethical issues, they insist that those who leave government service do not, for a period of time, enter into the employ of those where there might be a conflict of interest: Or, governments restrict the kinds of activities in which former public servants can be engaged. Certainly without such rules (but even with them) it would be unethical to give advice that favors those interests, without disclosing both the consequences for those groups and what might be viewed as the contingent interest of the advisor. (To be sure, the firms hiring these "devoted" public servants claim that they do so not as a reward for past services but on the basis of demonstrated acumen while in public service. It should be obvious that it is virtually impossible to draw the line between the two.)

Third, concern for social justice should make an economic advisor particularly attentive to the consequences of policies for the poor. Information does affect action, and although economists have a moral responsibility not to impose their values, they also have a moral responsibility to ensure the information is available on the basis of which moral policy decisions - for instance, decisions that reflect the principles of social justice-can be made. ${ }^{9}$ If a policy imposes risks on the economy, then the advisor should point that out, especially if the risks are borne disproportionately by the poor. To the extent possible, there is a moral responsibility to think creatively about what kinds of policies might enhance the opportunities for the poor, allowing them to take more responsibility for their own well-being. Similarly, since there is a moral imperative to be concerned with future generations, economists should be attentive to the policies' affect on the environment, and should provide information that can lead to better environmental policies. ${ }^{10}$

8 In the context of the Great Recession brought about by the financial crisis, the documentary movie Inside Job highlighted the many conflict of interest of several key economists in policy-making position and/or who had taken prominent public positions.

${ }^{9}$ I realize that there is a fine line that I am treading: I argued earlier that the economist should, in effect, distinguish the economist's role in defining opportunity sets from the political task of choosing among the points in the opportunity set. But the information supplied about the points in the opportunity set-for example, their impact on the poor-can affect the choices made. Someone not sharing the values, not concerned for the poor, might argue not only that providing that information is irrelevant, but also that it distorts the political process of decision making.

${ }_{10}$ We should thus view "green accounting" not just as a matter of providing a good accounting framework, but as a moral issue. 
These are general precepts that apply to all policy advisors. I have argued that one of the advantages of the institutional structure of the Council of Economic Advisers in the United States is that it reduces the scope for conflict of interests. ${ }^{11}$ The members are appointed for a short term and return to academia. Thus their incentive is to provide relatively accurate information, advice that will stand up to the scrutiny of their academic peers. The norms of the economics profession require making most of the distinctions I have alluded to, including distinguishing between special interests and general interests, efficiency effects and distribution effects. (Furthermore, US government regulations require that they dispense of all financial interests or put them into blind trusts; and in any case, few have substantial financial interests.)

One of the main activities of the international financial institutions is giving advice. In assessing the way that international financial institutions dispense advice, I feel that all too often they fall short on all counts described above. They push a particular set of policies, as loan conditionalities, rather than outlining the range of policies and trade-offs and then encouraging the countries themselves to take responsibility for choosing among alternative policies. They fail to clarify the uncertainties associated with the policies they promote, making assertions about the policies' efficacy that cannot be supported by evidence. Most importantly, at least in the past, they have not only failed to pay due concern to possible adverse effects of the policies on the poor, but they also have not even disclosed the likely risks. They have continually pushed policies entailing "pain," seemingly almost oblivious to who within the country has to bear that pain. Many of their policies seem to disproportionately benefit financial interests, and they fail both to point this out, and to disclose what I have viewed as the contingent interests of their staff-evidenced by the fact that many staff members leave the International Monetary Fund (IMF) or World Bank to work for private financial institutions. ${ }^{12}$

\section{Facing Moral Dilemmas AS AN ECONOMIC ADVISOR}

This brings me to perhaps the hardest moral question facing the policy advisor. What should he do when confronted with a policy that he believes is, in some sense, "immoral"? Should he speak out, but thereby risk possibly losing influence? Is silence a form of complicity? There are no easy answers, but a couple of examples may help illustrate the nature of the dilemma. When President Lyndon B. Johnson's economic advisors tried to forecast where the economy was going (and therefore what kinds of

\footnotetext{
11 See Stiglitz, Joseph. 1997. "Looking Out for the National Interest: The Principles of the Council of Economic Advisers." American Economic Review 87(2): 109-113.

${ }^{12}$ In 2002 , the number two person in the IMF moved directly from the IMF to take the vice-chairmanship of Citibank Group.
} 
macro-policies would be required to sustain noninflationary full employment), they were confronted with the following problem: The government was spending more on the Vietnam War than it would admit to. On the one hand, the advisors could pretend that the official numbers were correct, thereby recommending a clearly misguided fiscal policy. On the other hand, they could choose not to use the official numbers and instead to use more accurate numbers, but this would violate the "confidences" of government. But maintaining this confidence was in itself morally questionable: in democratic societies, one might argue there is a moral imperative for openness and transparency; after all, a public official is the "servant" of the people and the people have a right to know what the government is doing.

A few years later, President Ronald Reagan's economic advisor, Martin Feldstein, faced a similar problem. He had long argued for the importance of high national savings. Yet Reagan had pushed a tax cut that resulted in huge deficits, potentially undermining the future prosperity of the country. A few economists predicted that, contrary to all the evidence, the tax cut would generate enough growth so that there would not be a deficit. Intellectual honesty would require discussing the absence of evidence for that conclusion, and the risks associated with the high deficits. In this instance, Feldstein took a strong public stand, pointing out the potential adverse consequences of the policy; but in doing so, he undermined the effectiveness of the Council of Economic Advisers within the Reagan administration.

I faced a similar dilemma as chief economist at the World Bank. I believed the policies pursued by the IMF in the wake of the East Asia financial crisis would lead to deeper, longer recessions and depressions than necessary. I believed that the financial interests of the foreign creditors were placed above the concerns for the poor and small businesses. The policies pushed by the IMF, I believed, would almost surely wreak havoc on their lives and livelihoods. I tried, quietly and within the institutional processes, to change the policies, or at least to promote open discussion of the policies (given my belief that the errors were so obvious that any open discussion would quickly bring about a reversal of course). But with the great institutional rigidities (and the powerful special interests and their ideologies), I not only could not reverse policies, but I also could not even engender open discourse. It seemed to me that there was a basic moral issue: How could I remain silent? I felt a strong moral obligation to speak out, and at the very least, to point out the risks of these policies.

The moral stance of those who worked hard to quash public discussions had irreconcilable contradictions. They argued that open discussion could undermine confidence in the policies, and the lack of confidence would impede the desired effects. Thus, speaking out was, in their minds, wrong, because without the confidence, capital would continue to flow out of the country, and this capital outflow would further weaken the economy, hurting the poor. They were arguing, in effect, not only for a lack of openness and transparency, but also for a kind of dishonesty: asserting that the policies were likely to be more effective than the evidence warranted. The dangers of this stance should be obvious. In almost every arena, government could argue that dishonesty, partial truths, are "means" that justify the ends. To be sure, the Treasury or IMF may believe in their 
cases. But the Department of Defense may argue the same thing about every aspect of its activities (from the toxicity of Agent Orange to the true magnitude of the threat of an enemy $y^{13}$ ). Such positions are not only dangerous and undermining of democracy, but are also ultimately self-defeating. Repeated assertions of this kind destroy the credibility of government. In the economic arena, they are particularly problematic, because the predictions will frequently be proven wrong, and the ex post excuses always seem absurd. Indeed, the IMF's overconfident forecasts have created a lack of credibility that itself contributes to the lack of efficacy of the Fund's policies. In the end, this lack of credibility made my decision easier: whether I spoke out or not would have little effect on the confidence in the policy; but speaking out might have some effect on the policy chosen, thereby averting, or at least reducing, the recessionary consequences.

In general, there is no easy answer to these moral dilemmas facing the policy advisor. Each situation is different. One must make a critical judgment about which actions will most likely bring about the actions that one believes are morally right. In some cases, resignation may be the most effective answer; but even when that is contemplated, there is an important issue of timing. A well-timed resignation can sometimes bring about change more effectively than any amount of argumentation. The resignation is often seen as a costly move, and as such, the fact that a public official - who has often worked hard to obtain the prominent position-is willing to undertake such a measure provides an effective signal concerning the depth of feeling on the issue. ${ }^{14}$

\section{ETHICS AND INTERNATIONAL ECONOMIC POLICY}

I have argued that, though we expect individuals to act by and large in their self-interest, there are circumstances in which we say such behavior is unethical. So too for countries. We expect countries, by and large, to pursue policies that are in the interests of their citizens. But there are limits--behaviors that are unethical, or border on the unethical. To some, for a rich and powerful country to go back on its word is simply real politick: what can anyone do in retaliation? Some would go further, and say for government officials not to do so would be abrogating their responsibilities to their citizens, whose welfare they are supposed to be maximizing. If they can do so by lying, cheating, or stealing, so

\footnotetext{
${ }^{13}$ A point that was brought out even more forcefully by the events leading to the Iraq War, sometime after this speech was delivered.

14 A case in point, which emerged after the original version of this chapter was completed: Ravi Kanbur served as the director of the World Bank's decennial World Development Report on poverty. The version that he submitted for consideration emphasized not only income poverty, but also lack of voice and insecurity. The US Treasury (and in particular the Secretary of Treasury) insisted on the more narrow focus; with Kanbur's resignation, and the resulting civil society protest, the report that emerged reflected the original vision.
} 
macro-policies would be required to sustain noninflationary full employment), they were confronted with the following problem: The government was spending more on the Vietnam War than it would admit to. On the one hand, the advisors could pretend that the official numbers were correct, thereby recommending a clearly misguided fiscal policy. On the other hand, they could choose not to use the official numbers and instead to use more accurate numbers, but this would violate the "confidences" of government. But maintaining this confidence was in itself morally questionable: in democratic societies, one might argue there is a moral imperative for openness and transparency; after all, a public official is the "servant" of the people and the people have a right to know what the government is doing.

A few years later, President Ronald Reagan's economic advisor, Martin Feldstein, faced a similar problem. He had long argued for the importance of high national savings. Yet Reagan had pushed a tax cut that resulted in huge deficits, potentially undermining the future prosperity of the country. A few economists predicted that, contrary to all the evidence, the tax cut would generate enough growth so that there would not be a deficit. Intellectual honesty would require discussing the absence of evidence for that conclusion, and the risks associated with the high deficits. In this instance, Feldstein took a strong public stand, pointing out the potential adverse consequences of the policy; but in doing so, he undermined the effectiveness of the Council of Economic Advisers within the Reagan administration.

I faced a similar dilemma as chief economist at the World Bank. I believed the policies pursued by the IMF in the wake of the East Asia financial crisis would lead to deeper, longer recessions and depressions than necessary. I believed that the financial interests of the foreign creditors were placed above the concerns for the poor and small businesses. The policies pushed by the IMF, I believed, would almost surely wreak havoc on their lives and livelihoods. I tried, quietly and within the institutional processes, to change the policies, or at least to promote open discussion of the policies (given my belief that the errors were so obvious that any open discussion would quickly bring about a reversal of course). But with the great institutional rigidities (and the powerful special interests and their ideologies), I not only could not reverse policies, but I also could not even engender open discourse. It seemed to me that there was a basic moral issue: How could I remain silent? I felt a strong moral obligation to speak out, and at the very least, to point out the risks of these policies.

The moral stance of those who worked hard to quash public discussions had irreconcilable contradictions. They argued that open discussion could undermine confidence in the policies, and the lack of confidence would impede the desired effects. Thus, speaking out was, in their minds, wrong, because without the confidence, capital would continue to flow out of the country, and this capital outflow would further weaken the economy, hurting the poor. They were arguing, in effect, not only for a lack of openness and transparency, but also for a kind of dishonesty: asserting that the policies were likely to be more effective than the evidence warranted. The dangers of this stance should be obvious. In almost every arena, government could argue that dishonesty, partial truths, are "means" that justify the ends. To be sure, the Treasury or IMF may believe in their 
cases. But the Department of Defense may argue the same thing about every aspect of its activities (from the toxicity of Agent Orange to the true magnitude of the threat of an enemy ${ }^{13}$ ). Such positions are not only dangerous and undermining of democracy, but are also ultimately self-defeating. Repeated assertions of this kind destroy the credibility of government. In the economic arena, they are particularly problematic, because the predictions will frequently be proven wrong, and the ex post excuses always seem absurd. Indeed, the IMF's overconfident forecasts have created a lack of credibility that itself contributes to the lack of efficacy of the Fund's policies. In the end, this lack of credibility made my decision easier: whether I spoke out or not would have little effect on the confidence in the policy; but speaking out might have some effect on the policy chosen, thereby averting, or at least reducing, the recessionary consequences.

In general, there is no easy answer to these moral dilemmas facing the policy advisor. Each situation is different. One must make a critical judgment about which actions will most likely bring about the actions that one believes are morally right. In some cases, resignation may be the most effective answer; but even when that is contemplated, there is an important issue of timing. A well-timed resignation can sometimes bring about change more effectively than any amount of argumentation. The resignation is often seen as a costly move, and as such, the fact that a public official-who has often worked hard to obtain the prominent position-is willing to undertake such a measure provides an effective signal concerning the depth of feeling on the issue. ${ }^{14}$

\section{ETHICS AND INTERNATIONAL ECONOMIC POLICY}

I have argued that, though we expect individuals to act by and large in their self-interest, there are circumstances in which we say such behavior is unethical. So too for countries. We expect countries, by and large, to pursue policies that are in the interests of their citizens. But there are limits--behaviors that are unethical, or border on the unethical. To some, for a rich and powerful country to go back on its word is simply real politick: what can anyone do in retaliation? Some would go further, and say for government officials not to do so would be abrogating their responsibilities to their citizens, whose welfare they are supposed to be maximizing. If they can do so by lying, cheating, or stealing, so

${ }^{13}$ A point that was brought out even more forcefully by the events leading to the Iraq War, sometime after this speech was delivered.

14. A case in point, which emerged after the original version of this chapter was completed: Ravi Kanbur served as the director of the World Bank's decennial World Development Report on poverty. The version that he submitted for consideration emphasized not only income poverty, but also lack of voice and insecurity. The US Treasury (and in particular the Secretary of Treasury) insisted on the more narrow focus; with Kanbur's resignation, and the resulting civil society protest, the report that emerged reflected the original vision. 
be it. Again, however, one can argue against such behavior on instrumental grounds. In today's world even a powerful country needs the cooperation of others, and if it develops a reputation for mistreating others - for dishonesty, for breaking its word--it will find it more difficult eliciting that cooperation. The lack of trust has even more important consequences in the international arena than in the arena of domestic economics; in the latter, legal enforcement mechanisms can provide a partial substitute for trust. In the international arena, that is not the case.

In the following subsections, I review several recent issues in international economic policy through the lens of practical ethics. Each of these issues can be approached in other ways, and I do not intend to provide a comprehensive treatment of any of them. $I$ do believe, however, that approaching these issues from an ethical perspective provides new insights-including insights into why it is that some of these issues have taken on such moral overtones.

\section{Debt Forgiveness}

Debt forgiveness has become the subject of enormous public discussion. ${ }^{15}$ There seems something peculiar about very poor countries transferring money to richer countries year after year. Many countries have to spend a huge fraction of their export earnings to service their debts, leaving little remaining to spend on improving the plight of the poor. The debt overhang impedes growth and poverty reduction. Without debt forgiveness, prospects for these countries are bleak.

Here, I do not want to address the economic issues, but rather the moral issues and dilemmas. There are four, in particular, that have not received sufficient attention. The first concerns faimess among developing countries. The amount of resources transferred from the rich to the poor will, in any case, be limited. The question is, Who will receive these funds? The funds used for debt forgiveness could have been used to aid other needy countries, in particular countries that are equally poor, but had repaid their debt. It seems unfair, to say the least, that those who have lived up to the terms of the loan contract should be in the same or worse position than those who do not.

The second issue revolves around the moral responsibility of the lenders. Consider loans made to Mobutu Sese Seko in his heyday. The lenders knew of his corruption. They knew that the money would not go to the people in the country. At best, it was Cold War lending, pure and simple. At worst, it was lending to ensure that Western companies could continue to exploit the rich natural resources of that country. Why should the people of Zaire - who had no say in the choice of Mobutu as their leader-have had to pay for the money that was given to him, and which he squandered? Doesn't the moral responsibility lie with the lender? (Such debts have come to be called otiose debts, with many critics of the lending policies suggesting that there is no moral obligation on the

15 This chapter was written at the time of the Jubilee movement, which successfully called for large-scale debt forgiveness for the world's poorest countries. 
part of the debtor to repay the debt, and that there is a moral obligation on the part of the creditor to forgive the debt.) In any case, every loan is a voluntary transaction between the lender and the borrower; as such, if a loan is made that shouldn't have been, the lender is as much at fault as the borrower. Indeed, in a fundamental sense, he may be more to blame: lenders have better knowledge of risks, and they typically have been rewarded for those risks by interest rates that are in excess of the safe interest rate, sometimes considerably so.

The case just described seems like an easy one, where the moral responsibility of the lenders cannot be avoided. But there are cases that might seem slightly more problematic. Consider the 1998 IMF loan to Russia. In that case, there was an elected government, though one for which there was considerable evidence of corruption. It was perfectly clear at the time that Russias exchange rate was overvalued; the overvalued exchange rate was having an adverse effect on their economy; the IMF-imposed contractionary policies (part of the conditionalities imposed for assistance) caused a deep plunge in its economy leading to enormous increases in poverty (from 2 percent under the previous regime to almost 50 percent by 1998); and the policies of privatization and free capital outflows that the Fund also had pushed led to a few oligarchs accumulating huge amounts of wealth. Should the IMF have lent billions of dollars to the country knowing what it did? They knew full well that there was a high likelihood the funds would simply enable a few oligarchs to take more money out of the country, and that it would saddle the country with increased indebtedness. They knew that the poor taxpayers would eventually have to pay back the funds borrowed. And they knew that, in any case, lending was unlikely to facilitate the resumption of growth (and indeed, by sustaining the exchange rate at an overvalued level, actually had an adverse effect on growth). If the IMF did lend the country money, and if the money then was, in effect, used to enable oligarchs to take more of their wealth out of the country on more favorable terms, and if the economic polices failed, what is the moral obligation of the citizens of the country to repay the loan, or of the Fund to forgive the loan? What is the moral responsibility for their misguided advice, for their complicity in providing funds where there was such a high likelihood of abuse?

The third issue concerns the nature of the debt contract, and the advice given to the countries. In well-functioning capital markets, the risk associated with any contract is divided among the parties, with the party most able to bear the risk bearing the risk disproportionately. But capital markets do not work as well in practice as they do in theory. It is the developing countries that bear the brunt of the risks associated with exchange rate and interest rate changes, and it is large changes in exchange rates and interest rates that have led many of the countries to their current predicament. The international financial institutions, of course, have the opportunity-I might say the obligation-to design contracts that reflect an appropriate sharing of the risk burden, but they have failed to do so. And they have failed, in many cases, to advise the country of the risks associated with the borrowing policies that they recommended. For instance, prior to the Russian 1998 crisis, the IMF advised Russia to borrow in dollars, seemingly because the interest rate was lower. But the IMF, of all institutions, believes in well-functioning 
markets and should have also pointed out that if markets were working well, then the differences in interest rates (between the dollar and ruble rates) reflected the risk of exchange rate change, and that if Russia did borrow more in dollars, the consequences in the event of a devaluation (which at the time seemed highly likely) would be very severe. The moral weight for debt forgiveness seems greater because of these poorly designed contracts and the incomplete, and in some cases, misguided advice.

The fourth issue relates to the conflict of interest that I brought up earlier in this chapter. One of the functions of the large bailout loans has been to provide funds with which Western banks can be repaid. There are potential conflict of interest (at the individual ${ }^{16}$ and organizational levels ${ }^{17}$ ): much of the benefits to these loans arguably go to the banks and other Western financial interests, with the costs being borne by workers and others within the country. Ethical advice and lending practice would require that this be pointed out. When there has not been adequate disclosure, what is the moral obligation of the borrower to repay, or of the lender to forgive?

Ethical issues associated with repaying debts, and debt enforcement, are longstanding and complicated. Over time, there has clearly been a change in ethical views. Debtor prisons were employed in the 19th century in Britain. Most people today would view such treatment as cruel punishment, unethical, no matter how strong the incentives for repayment it provides. Similarly, bonded labor, sometimes used as a debt enforcement mechanism in developing countries, is not only illegal in most countries, it is also unethical-just a step away from slavery. For a country to march into another to enforce a debt contract would also today be viewed as unethical, though it occurred several times in the 19th century. At the individual level, usurious interest rates and the imposition of other "conditions" associated with loan-sharking are viewed as unethical. The extensive conditionalities imposed by the IMF in the context of the loans to countries in desperate need for funds raise similar questions: When do such conditionalities represent an abuse of power, and in that sense, are they unethical? These are questions I briefly touch upon later.

\section{Providing Loans}

In approaching the problem of whether to give a country a loan, a simple question needs to be posed: Will the country, as a whole, be better off with the loan than without it, tak ing into account that it will be more indebted? If there is a reasonable chance that the country will be worse off, the moral case (as well as the economic case) is questionable The incentives of the lending institution and its staff and the incentives of the borrowing

\footnotetext{
16. That is, many of those responsible for making the loans have, and will have, connections with the financial institutions being bailed out.

${ }^{17}$ That is, finance ministries (US Treasury) and central banks, with close ties to the financial community in the advanced industrial countries-the lenders-are responsible for the lending decisions.
} 
government may differ markedly from these moral dictates. The government may feel that the money will give it a chance to survive; if the money fails to work, it will be someone else's problem. To return to the IMF loan to Russia, one of the arguments for giving the money was that it would enhance the political survival of Boris Yeltsin, whom the United States and the IMF viewed as a friend. More to the point, the downfall of Yeltsin would be seen as a failure of IMF and US Treasury policy. The incentives of the IMF and the US Treasury did not necessarily, in this sense, coincide with the interests of Russia, though to be sure, the IMF and US Treasury might have thought that they were in a better position to make the appropriate political judgments than were the voters in Russia. (The discrepancy between individual and organizational incentives has been emphasized in the organizational literature; for instance, the theory of escalating commitment points out that the cost to an individual of abandoning a strategy that he has advocated may be greater than the cost to the organization.).

To provide another example: in the recent Argentina debacle, at the time of the August 2001 loan, even IMF Board members were skeptical that the money was going to make any difference. The country would be left more in debt, but the likelihood that it would enable the country to survive for more than a few months without a major default or devaluation was slim. It could conceivably be viewed, however, in the interests of a very senior official, who was about to depart. Not lending would have precipitated a crisis then and there, and it would have made apparent that the policies he had pushed had been a dramatic failure. If there was even a small chance that the program might work, his policies might be vindicated. If they failed, he did not bear the costs: it was the people in the country that bore the increased indebtedness. So cynical had some of the Board members become at this juncture that they talked about the $\$ 8$ billion as a going away present for the departing official; the money was likely to hold things together until he left the Fund, sparing him the immediate embarrassment, but not much longer.

In short, there are reasons to believe that the interests of the borrowing government and lending institution (IMF) may differ markedly from those of the people in the country. The IMF and its staff would like to persuade others that they are unlike other public and private institutions: although they recognize the role of rent seeking and distorted incentives especially in governmental institutions, they themselves believe that they are immune from such distortions. There is little in the way of theory or evidence to support such a view. When money was lent to a country for reasons other than promoting the development of the country (e.g., to maintain friendship with the ruling government in the Cold War), the ethical case for debt forgiveness is enhanced; the moral obligation for repayment is reduced.

Of course, in the case of private lending, there may not even be a pretense that it is in the long-run interests of the country. The lenders may make their money up front and often don't have to bear the full risk of the loan going bad-especially if they can syndicate the loan and/or if they can count on a bailout by the IMF.

So far, I have emphasized that there are numerous instances in which loans have been given when they arguably should not have been, raising ethical issues about repayment. There are similar issues when there are circumstances in which one might argue that 
loans should be given but the money is withheld, or conditions are imposed, taking advantage of the weakened position of the borrower. Ecuador provides a possible example. Providing money at a critical stage to a country facing a liquidity crisis because of a series of adverse shocks, including low oil prices, a weak agricultural position because of El Niño, or a disease affecting shrimp-one of its major export crops--would have made economic sense and would have been the ethical thing to do. And because of Ecuador's oil reserves, its long-term financial position was more positive. It might have enabled the survival of a democratically elected government. But the IMF had been extensively criticized for large bailouts; there was pressure for a policy of "bail-ins"--private sector participation. It was too risky to try this new strategy on rich and powerful countries like Brazil and Russia; weak countries like Romania and Ecuador were chosen for the experiment, with adverse consequences for both.

\section{Developed Countries' Trade Policy}

The riots in Seattle brought home the extent of dissatisfaction with the way that international trade negotiations have been conducted, and are likely to be conducted in the future. ${ }^{18}$ The agenda had been set by the rich and powerful countries, to reflect vested interests in their countries. And the outcomes had reflected their economic power. Indeed, by one calculation, sub-Saharan Africa was actually worse off after the Uruguay round of trade negotiations (which was completed in 1994) than before. The United States pushed for liberalization of financial services and information technology and for more extensive protection of intellectual property. It was less concerned about other services, such as marine and construction, or even the potential adverse effects of the rigid enforcement of intellectual property on those in the developing countries whose lives depended on the availability of cheap drugs. In trade negotiations with Korea (and other countries), it pushed for rapid financial and capital market liberalization, knowing full well the risks that those policies imposed on the country. ${ }^{19}$ The welfare of the US financial community was put above the welfare of the developing countries' workers. In dragging its feet in negotiations leading up to the admission of China to the World Trade Organization, the United States went so far as to argue that China was not a developing country-though the World Bank (and every other international agency) classifies it as such.

18 For a moment, with the signing of the agreement marking the beginning of the Development Round trade negotiations in Doha in November, 2001, it seemed that the West had become aware of the imbalance, and that the inequities would be rectified. What happened in the subsequent years showed, however, that that was not to be the case.

19 This policy was pushed by the US Treasury, even though the Council of Economic Advisers not only warned about the risks imposed by the policy and the dubious benefits to the country, but also argued that there were few benefits to the United States as a whole. The policy was another example of special interests having sway. 
At one level, it is natural for a country to pursue its own interests. But, as I asked earlier, at what point does this pursuit of a country's own interest (or, as is more frequently the case, special interests within one's country) at the expense of the poor, become a moral issue?

There is one aspect of these discussions that particularly troubles me as an economic advisor: when the arguments used for the US position border on hypocrisy and dishonesty. For instance, while the United States (and the IMF) lectured developing countries on the evils of subsidies and the virtues of free trade, Western governments maintained huge subsides and trade barriers in agriculture, the areas of comparative advantage for many developing countries. The United States and Europe accused others of dumping-and under that ruse created new trade barriers-even though few economists would characterize what the countries were doing as dumping. It would have been better to be more honest and forthright, to admit that political pressures at home forced us to have policies that were hard to justify.

\section{GLOBAL ExTERNALITIES: The Global ENVironment}

We teach our children early on that it is wrong to litter. This is an example of an externality, an action by one individual that affects others and for which that individual does not bear the costs. Government policies are designed to limit the extent of externalities, but they are imperfect. Social control mechanisms - a sense of what is right and wrong, ethical presuppositions - are more effective. The actions of those in one country similarly have effects on others, and given the absence or weaknesses of international law, there is a need for reliance on ethical norms. For instance, it is wrong for a country to locate a garbage dump on its boundary so that the downward wind pollutes the air of its neighbor.

The realization that we all share the same planet, that its resources are limited, and that bad policies can squander those resources, leaving future generations at risk, has come about only slowly. There is now general recognition of the dangers of global warming, and the Rio and Kyoto conventions are testimony to this global concern. But there is a deeply troubling aspect of the framework of these conventions. It is based on cutbacks in current emission levels. It is hard to detect an underlying principle of equity: the developed countries seem to have the right to pollute more than the less developed countries (on a per capita basis) simply because they have polluted more in the past. Is there any moral justification for such a policy? There are alternative frameworks, involving, for instance, agreements to undertake common policies (e.g., universal taxes on carbon emissions) that would seem to have a stronger ethical basis. The ethical stance of the United States, the largest emitter of greenhouse gases, both on a per capita basis and absolutely, is even harder to comprehend. ${ }^{20}$ It claims that it need not do anything because the developing countries have not bound themselves to doing anything, even

20 Since this chapter was written, China has overtaken the United States as the largest emitter of greenhouse gases, though the United States still remains, by far, the largest polluter on a per capita basis. 
loans should be given but the money is withheld, or conditions are imposed, taking advantage of the weakened position of the borrower. Ecuador provides a possible example. Providing money at a critical stage to a country facing a liquidity crisis because of a series of adverse shocks, including low oil prices, a weak agricultural position because of El Niño, or a disease affecting shrimp-one of its major export crops-would have made economic sense and would have been the ethical thing to do. And because of Ecuador's oil reserves, its long-term financial position was more positive. It might have enabled the survival of a democratically elected government. But the IMF had been extensively criticized for large bailouts; there was pressure for a policy of "bail-ins"--private sector participation. It was too risky to try this new strategy on rich and powerful countries like Brazil and Russia; weak countries like Romania and Ecuador were chosen for the experiment, with adverse consequences for both.

\section{Developed Countries'Trade Policy}

The riots in Seattle brought home the extent of dissatisfaction with the way that international trade negotiations have been conducted, and are likely to be conducted in the future. ${ }^{18}$ The agenda had been set by the rich and powerful countries, to reflect vested interests in their countries. And the outcomes had reflected their economic power. Indeed, by one calculation, sub-Saharan Africa was actually worse off after the Uruguay round of trade negotiations (which was completed in 1994) than before. The United States pushed for liberalization of financial services and information technology and for more extensive protection of intellectual property. It was less concerned about other services, such as marine and construction, or even the potential adverse effects of the rigid enforcement of intellectual property on those in the developing countries whose lives depended on the availability of cheap drugs. In trade negotiations with Korea (and other countries), it pushed for rapid financial and capital market liberalization, knowing full well the risks that those policies imposed on the country. ${ }^{19}$ The welfare of the US financial community was put above the welfare of the developing countries' workers. In dragging its feet in negotiations leading up to the admission of China to the World Trade Organization, the United States went so far as to argue that China was not a developing country-though the World Bank (and every other international agency) classifies it as such.

\footnotetext{
18 For a moment, with the signing of the agreement marking the beginning of the Development Round trade negotiations in Doha in November, 2001, it seemed that the West had become aware of the imbalance, and that the inequities would be rectified. What happened in the subsequent years showed, however, that that was not to be the case.

${ }_{19}$ This policy was pushed by the US Treasury, even though the Council of Economic Advisers not only warned about the risks imposed by the policy and the dubious benefits to the country, but also argued that there were few benefits to the United States as a whole. The policy was another example of special interests having sway.
} 
At one level, it is natural for a country to pursue its own interests. But, as I asked earlier, at what point does this pursuit of a country's own interest (or, as is more frequently the case, special interests within one's country) at the expense of the poor, become a moral issue?

There is one aspect of these discussions that particularly troubles me as an economic advisor: when the arguments used for the US position border on hypocrisy and dishonesty. For instance, while the United States (and the IMF) lectured developing countries on the evils of subsidies and the virtues of free trade, Western governments maintained huge subsides and trade barriers in agriculture, the areas of comparative advantage for many developing countries. The United States and Europe accused others of dumping - and under that ruse created new trade barriers--even though few economists would characterize what the countries were doing as dumping. It would have been better to be more honest and forthright, to admit that political pressures at home forced us to have policies that were hard to justify.

\section{GLOBAL EXTERNALITIES: The GLOBAL ENVIronMENT}

We teach our children early on that it is wrong to litter. This is an example of an externality, an action by one individual that affects others and for which that individual does not bear the costs. Government policies are designed to limit the extent of externalities, but they are imperfect. Social control mechanisms-a sense of what is right and wrong, ethical presuppositions-are more effective. 'The actions of those in one country similarly have effects on others, and given the absence or weaknesses of international law, there is a need for reliance on ethical norms. For instance, it is wrong for a country to locate a garbage dump on its boundary so that the downward wind pollutes the air of its neighbor.

The realization that we all share the same planet, that its resources are limited, and that bad policies can squander those resources, leaving future generations at risk, has come about only slowly. There is now general recognition of the dangers of global warming, and the Rio and Kyoto conventions are testimony to this global concern. But there is a deeply troubling aspect of the framework of these conventions. It is based on cutbacks in current emission levels. It is hard to detect an underlying principle of equity: the developed countries seem to have the right to pollute more than the less developed countries (on a per capita basis) simply because they have polluted more in the past. Is there any moral justification for such a policy? 'There are alternative frameworks, involving, for instance, agreements to undertake common policies (e.g., universal taxes on carbon emissions) that would seem to have a stronger ethical basis. The ethical stance of the United States, the largest emitter of greenhouse gases, both on a per capita basis and absolutely, is even harder to comprehend. ${ }^{20}$ It claims that it need not do anything because the developing countries have not bound themselves to doing anything, even

20 Since this chapter was written, China has overtaken the United States as the largest emitter of greenhouse gases, though the United States still remains, by far, the largest polluter on a per capita basis. 
though the build-up of greenhouse gases is largely due to the advanced industrial countries, and even though, were they to make a commitment not to emit at levels that exceed those of the United States on a per capita basis, it will be decades before that constraint will be binding.

\section{INTERGENERATIONAL EQUITY, The Environment, Population Policy}

There are moral dimensions not only to how we treat others who are alive today, but also how we treat future generations. By using up natural resources, without leaving compensating endowments of physical capital, we leave future generations more impoverished. This violates principles of intergenerational equity or social justice. Many developing countries today are exploiting their limited natural resources, without adequate provisions for the future. There are accounting frameworks (green accounting) that are designed to encourage better intergenerational equity. Governments should be encouraged not only to use such accounting frameworks, but also to set aside funds or to invest in physical and human capital.

Perhaps the most important determinant of environmental degradation (including that related to carbon emissions) is population growth. Population growth imposes a wide variety of externalities (a point recognized long ago by Edgeworth ${ }^{21}$ ). Countries with high rates of population growth have a hard time increasing incomes (per capita), and thus face a greater prospect of increasing poverty. Indeed, in the last decade of the last century, in the race between improving standards of living and population growth, the latter won: while the percentage of the population in poverty fell, the absolute number of people living in absolute poverty increased. Those with large families not only have a hard time feeding their children (and childhood malnutrition has lifelong effects), but they cannot afford to educate them, thereby condemning another generation to poverty and suffering. We now have the means of controlling population. I would argue that there is a moral obligation for governments to pursue such policies.

\section{CRISES}

Earlier, I briefly alluded to the moral dilemmas I saw when confronting the East Asia financial crisis. I do not want to address here the problem of parsing out "blame" for the crisis and the failed management of the crisis. I want to focus on the ethics of

${ }^{21}$ Edgeworth, Francis Ysidro. 1925. Papers Relating to Political Economy. London: Macmillan. 
international advice and assistance. To be sure, policies within the affected countries did contribute to the crisis: corruption and inadequate financial regulation played their part. But that is not the issue. The issue is how to intervene in the crisis in ways that minimize the damage, particularly to the poor, providing at the same time the foundations for correcting the underlying problems. The IMF failed to do this. ${ }^{22}$ The interests of foreign creditors were put ahead of the concerns for the workers and small businesses, with devastating effects, from soaring unemployment to plummeting wages. These parties were innocent bystanders; it was not their borrowing that had led to the crisis. Food subsidies for the poor were cut, just when they were most needed. The political and social unrest-with many people dying-was predictable, and predicted.

What is the moral responsibility for those who push for the policies that had such disastrous consequences? Especially when their prior advice, encouraging and even demanding rapid capital market liberalization, was probably the single most important factor contributing to the occurrence of the crisis in the first place? And, even more so, when the policies put forward fail to have the predicted outcomes, the IMF and the US Treasury shifted blame to the country-and in doing so contributed fur ther to investor flight. As Jeffrey Sachs pointed out, it was like crying fire in a crowded theater. Not only is doing so bad economic policy, and an abuse of the trust and confidence placed in the institutions. It is also arguably a fundamentally immoral act, just as crying fire in a crowded theatre-knowing that doing so might generate a riot and needless death-would be an immoral act. These are questions that all too seldom have been raised within international institutions or the governments that dominate their policies. But they are the questions that are increasingly being asked by ordinary citizens both in the developing world and in the more advanced industrial countries.

The governments in power, which acquiesced in those policies, bear some responsibility, but they often view themselves as having no choice-and indeed, were told that they did not in effect have any choice. The outside advisors did have a choice in the advice they prescribed. Indeed, there was controversy about the appropriateness of different policies. Thus, the issue is not whether the affected countries themselves and their governments bear some responsibility; they do. Rather, my concern here is the moral culpability of the IMF, which it has yet to recognize.

22 The IMF has claimed that the quick recovery of several of the countries affected by the crisis is proof that its medicine works. A closer look at the pattern of recoveries does not support this conclusion, as I argue elsewhere. The country that has been the most assiduous follower of the IMF prescriptions, Thailand, years after the crisis still had a GDP below the pre-crisis level, and almost 40 percent of loans were still nonpexforming. Malaysia had a quick recovery, but never had an IMF program. Indonesia, too, remained in a deep recession for years, partly attributable to the riots that were inspired by the failed IMF policies, partly attributable to the fact that those policies led to massive bankruptcies from which the country was slow to recover, and partly due to the strategy of restructuring the financial system, which led to runs that undermined the entire private banking system. Korea's relatively quick recovery in part was due to the fact that it did not listen to the IMF at key points: had it followed their advice in disposing of the so-called excess capital in the chip industry, it would have missed out on the global turnaround in that market that fueled the recovery. The growth in Russia and Brazil was because of the devaluations, which the IMF policies only delayed. 
I want to briefly refer to several of the ethical dimensions of the IMF's behavior. First, in providing its advice, advisors did not act honestly in conveying the risks and uncertainties and in presenting the range of alternatives. Second, there is the issue of the trade-off between devaluations and interest rate increases and moral issues concerning responsibility. The IMF held that only by increasing interest rates could they forestall further declines in the exchange rate. In fact, the high interest rate policies were ineffective in forestalling the decline in the exchange rate, and may have actually contributed to it: by helping to deepen the recession/depression, capital was induced to flee, rather than be attracted into the country. But this mistake in economic judgment ${ }^{23}$ should not be confused with the deeper moral issue. At the root of the crisis in several of the countries was excessive borrowing abroad. Those borrowing could have-and most economists would say, should have-obtained "cover" (effectively insurance) against a change in the exchange rate. No government guarantees its exchange rate; and there is no such thing as fixed exchange rates. Exchange rates change; the only difference in regimes concerns the frequency, magnitude, and more generally the rules that govern those changes. The market was, in effect, telling borrowers that there was a risk of devaluation (in equilibrium, the difference in interest rates at home and abroad is equal to the expected rate of change of the exchange rate, plus a risk premium). The stance of the IMF, once the crisis occurred, was to bail out those who had gambled on the exchange rate not changing (who had not bought cover), at the expense of the innocent bystanders. In a sense, those who caused the crisis, by borrowing excessively abroad in the short term, were let off the hook (at least partially), at the expense of those who were only engaged in normal business borrowing. Put this way, the bailout raises disturbing moral issues, beside the broader moral hazard issues that have been extensively discussed (the pattern of IMF inspired bailouts reduce the incentive of those borrowing abroad to obtain cover as well as the incentives of lenders to engage in due diligence in assessing credit worthiness.)

\footnotetext{
23 There were other mistakes in economic judgment: the IMF concluded (without deep empirical work) that allowing the exchange rate to fall would harm the economy more than letting interest rates rise. In fact, in several countries, this was almost surely not the case. For instance in Thailand, those who borrowed abroad were the real estate firms (and those who had lent to them), who were already dead, in the wake of the collapse of the real estate bubble, and for whom a further fall in the exchange rate would have had little effect (though it may adversely affect the amount that foreign creditors could obtain); and exporters, who would gain as much in earnings as they would lose on their balance sheet. Perhaps the reason that they did not go into a close empirical evaluation of the effects was that that was not really their concern; they were more focused on the impact of the countries' ability to repay the loans to the creditors that they represented in the advanced countries (e.g., US and European banks). But this change in mandate from the purposes for which the institution was created-to help sustain a country in the face of a threatened downturn - and this obfuscation of the true objective of the policy (if correct) is itself deeply troubling, and raises moral issues.
} 


\section{Growth ANd Poverty Reduction STRATEgIES}

Today, everyone pays obeisance to the importance of reducing poverty. The IMF changed the name of its program for developing countries from Enhanced Structural Assessment Facility (ESAF) to incorporate the words "poverty and growth." Trickle-down economics-whereby one justifies programs that make the rich still richer by arguing that the benefits eventually trickle down to the poor-is no longer in fashion. But putting thetoric aside, there is an active debate concerning economic policies. The position of the US Treasury and the IMF can be characterized as "trickle-down plus": growth is necessary and almost sufficient for reducing poverty, and consequently the best strategy for helping the poor is to adopt growth-maximizing reforms-the same neoliberal agenda, with its emphasis on privatization and liberalization, that prevailed over the past two decades, augmented by education and health. The modifications in the traditional formula represent important steps in the right direction. But the underlying prescription is faulty in several respects. The fact of the matter is that the countries that have been most successful in development over the past half a century-the countries of East Asia-have not followed the Washington Consensus policies. And many of the countries that have followed the Washington Consensus policies have not done particularly well (though the "doctor" claims that the prescriptions were not followed sufficiently closely). Honesty should have dictated full disclosure: the evidence in favor of the Washington Consensus policies is at best mixed; and failing to provide such honesty raises moral issues. ${ }^{24}$

But perhaps more important, concern for the poor should have dictated greater attention to the consequences of the policies for poor, and an awareness that the countries that have done the best job of reducing poverty have gone well beyond a reliance on trickle-down economics. Some examples help illustrate what I have in mind:

- The countries that have done best in improving the plight of the poor have had an explicitly pro-poor growth strategy that goes beyond simply paying lip service to education and health.

- Unless the poor are given assets-such as in land reform - they are likely to remain mired in poverty. But land reform may challenge vested interests. It is curious that although those who currently own large amounts of wealth in many of the poor countries acquired this wealth in ways that have little legitimacy (e.g., through the exercise of brute force by colonial masters), taking wealth away from these individuals is viewed as an abrogation of basic values of "property rights."

\footnotetext{
24 Interestingly, in the 1996 World Development Report: "From Plan to Market" on transition, the most successful transition - that of China - is given short shrift, being relegated largely to "boxes." Was this because its success-including its success in reducing poverty-ran so counter to the prevailing orthodoxy?
} 
- The disparity between the ownership of resources (such as land) and labor results in institutions, like sharecropping, that lead to attenuated incentives and reduced output. Under sharecropping, tenant farmers face, in effect, a tax rate of 50 percent (or more). Although the IMF speaks out strongly against high tax rates, and their enervating effects on effort, it has not spoken out as strongly in favor of a land reform that reduces these agency problems and increases economic efficiency at the same time that it increases equity.

- Some of the economic reforms advocated by the IMF and the US Treasury have dubious effects on growth, but increase the country's vulnerability to shocks. (Capital market liberalization represents the most obvious example.) It is the poor who inevitably bear the brunt of the downturns, regardless of the lip-service paid to the importance of creating safety nets. Honesty would require observing that even in the most developed countries, safety nets for farmers and the self-employed are inadequate.

- Even the benefits of trade liberalization become questionable unless accompanied by measures that enable the creation of new enterprises and jobs. But IMF packages often have accompanied trade liberalization measures by high interest rates that would make job creation a virtual impossibility, even in a well-functioning market economy. The point is a simple one: trade liberalization often leads to a loss of jobs. The free market ideology argues that this enables a flow of resources from less efficient uses to more efficient uses. Were that the case! The problem is that in many less developed countries markets do not work well (that is part and parcel of being less developed). Unemployment rates are high. Job creation is difficult. Moving labor from low productivity jobs to unemployment decreases a country's GDP and increases poverty. But often, that is precisely the effect of IMF packages combining liberalization with high interest rates.

- And even if the country is successful in creating new jobs, the poor may be adversely affected, because greater openness can lead to greater sensitivity to shocks from the outside world, the brunt of which is borne by the poor. Insecurity is one of the major problems facing the poor, and policies that increase that sense of insecurity adversely affect the plight of the poor.

- Privatization programs have often had adverse effects, particularly on the poor. The rapid privatization programs have led to privatization of monopolies, without regulatory oversight; and these monopolies, though they may or may not have proven more efficient in production, have sometimes proven more efficient in exploiting consumers. Privatization has proven an important vehicle for both corruption and increasing inequality, a point brought out forcefully by the experiences in Russia. Indeed, one of the incentives for rapid privatization was that those that received state assets below market value then made a contribution (not just in terms of finance, but also in terms of the even more valuable organizational support and media coverage) to support Yeltsin's reelection. The silence in the face of the corrupt loans-for-share deal spoke loudly: the means seemingly justify the end! 
- The IMF has taken a particularly narrow (and peculiar) definition of good budgetary policy, in which foreign aid is not included, or is discounted, as a revenue source. The alleged reason for this is that foreign aid is volatile, and therefore cannot be counted upon. The World Bank analyzed this allegation, and showed that tax revenues were even more volatile. Hence, according to Fund logic, tax revenues should not be included in revenues either, in which case no country is in budgetary balance. More to the point, the appropriate response to volatile income flows is flexible expenditures. Countries build new schools and health clinics as they receive the money; when the aid stops, so does the construction. In long discussions with the Fund, I have never seen an adequate justification for the Fund's stance. But the consequences should be clear. It means that an increase in foreign aid may not result in more schools or health clinics, only more money going to the country's reserves.

The economics of these policies has long been debated, both within the economics profession and within civil society. My point in raising these issues is not to rehearse that debate, but to emphasize the moral dimension. The budgetary stance of the Fund means that fewer schools and clinics are built, to the detriment of the poor. Other policies described above increase the risks faced by the poor. In some cases, such as capital market liberalization, these policies seem of questionable benefit to the country as a whole, though they might bring benefit to the financial communities both within the country or, more likely, abroad. But there have been sins of omission as well as commission: land reform would have arguably increased both equity and efficiency.

In retrospect, as we look back at the colonial policies, at the unfair trade treaties foisted on Japan, at the Opium Wars, we shudder at their seeming lack of moral justification. We look with derision at writings describing the White Man's Burden, especially in light of its legacy in Africa and in so many other places in the colonial world. We no longer use military power to open markets or to enforce debt contracts, but the advanced industrial countries do use their economic power. They use their economic power to forge international agreements in which disproportionate benefits accrue to the developed countries, and in which, the less developed countries are sometimes even worse off. In this section, I have asked whether the same objections raised to colonialism could, in fact, be applied to the economic policies foisted on these countries. Even when they help the poor, are there alternative policies that might have helped them even more, or that would have imposed less risk on them? Have the international institutions that have pushed these policies been honest in portraying these risks? Have they been dishonest in exaggerating the evidence concerning their economic benefits? (Certainly, the benefits promised from economic reform in Russia have far exceeded what has been delivered.) Perhaps we should ask, Will our children's children look at current economic relationships with the same shock - the same sense of moral outrage with-which we look at the colonial experience? The experiences in Seattle and Washington, and extensive conversations with young people around the world, suggest that we may not have to wait for these reactions: the youth of today are questioning the moral legitimacy of 
these policies. The defenders of these policies claim there is no alternative; there is a single recipe for success. In this they are wrong, and if there was a single best recipe, the countries that have succeeded in simultaneously growing and reducing poverty would have given credence to the view that it is not the one that the international institutions have prescribed, with their inadequate attention to democratic, equitable, and sustainable development.

\section{A General Perspective}

Ethics has to do with an individual's relationship with other individuals, with the community and with society more broadly. Ethics involves the recognized moral rules required to live together in well-functioning communities. It is wrong to murder or assault or otherwise cause harm to another. But in modern societies harm to others can be done in a variety of ways-when an individual litters, he harms the environment, and hence injures the well-being of anyone who values the environment. Simple maxims such as "do unto others as you would have them do unto you" or "don't do unto others as you would not have them do unto you" and touchstones such as Kant's categorical imperative provide widely accepted guidelines, though to be sure, the world is complex enough that the application in particular circumstances may not be obvious, or even unambiguous. Earlier, we observed that from today's vantage point, we look on slavery with abhorrence, and view colonialism - and the colonial mentality-as a violation of basic ethical norms. But is one person's-or one country's-imposition of his will on another, by force of economic power more acceptable than an imposition by force of military power? In the 19th century, the two were often intertwined, with military power being used to enforce economic obligations. Today, matters are, perhaps, more subtle, but does this make them any more acceptable? In ordinary life, it would be viewed as a breach of ethical norms to take advantage of an individual's temporary misfortune, but at the international level, this is sometimes seen as simply the natural state of affairs. Should the imposition of conditions on the countries that needed finance in the 19971998 crisis - conditions that were unrelated to the crisis, or to the repayment of the loan-be considered a breach of ethical norms? Even if it is (at least from the perspective of the party imposing the conditions) for the good of the other party?

Many ethical precepts are concerned with actions that undermine "community." The development process, no matter how well it is carried on, typically undermines some traditional values, some aspects of traditional culture. But if carried on in the wrong way, it can have a devastating effect. The way that the transition from communism to a market economy was carried out in Russia was a disaster, by any account, with poverty soaring and output falling, while a few people garnered huge riches for themselves. No wonder there has been a complete erosion in the sense of community, in basic norms of behavior, matched by the growth of "mafia" activity. Economists have begun to talk about these ideas in terms of the concept of social capital. One of the reasons for the difference between China's successful transition and Russia's failure is the relative preservation of 
social capital in the former and its destruction in the latter. ${ }^{25}$ But we also know that economic policies play a critical role: transitions accomplished through Bolshevik means, or with Bolshevik speed, or with the Bolshevik lack of concern for building social consensus, are more likely to lead to an erosion of social capital. In the case of Russia, the rapid privatizations helped erode what little social capital was left over from the communist reign: they resulted in a few individuals seizing control of vast assets formerly owned by the state, with free capital mobility almost inviting them to take their ill-begotten gains abroad, while the state claimed it did not have enough resources even to pay pensions.

We often talk about the "social contract." The social contract is never formally written down, but it can nonetheless still be broken, or be perceived to be broken. Hyperinflation is widely criticized because it undermines the social contract. What happened in Russia has been widely viewed within as a violation of the social contract. While the IMF argued during the midst of the $1997-1998$ crisis that not repaying creditors was a violation of the sanctity of contracts, even though bankruptcy is a central institution in capitalism, they seemed to pay little attention to the violation of an even more important contract, the social contract.

If, as a result of the erosion of the social contract, there is a weakening of social cohesion, in ways that lead to more violence, more corruption, and more crime, then what is the culpability of those who have contributed to this evisceration of social capital? To what extent should they be held morally responsible for the consequences, especially when these consequences are the predictable-if not inevitable, at least highly likely-result of their actions?

I am raising here some fundamental issues: earlier, I argued that economic policies often give too little attention to their effect on the poor, to the sense of security. I suggest that this is a violation of basic ethical precepts. But economic policies are typically even less concerned with their impact on the community, on traditional social safety nets and traditional relationships. "Flexible labor markets" mean that employers should feel free to discharge workers as soon as they are not needed; there is no moral obligation to see workers through the hard times. Any policy that undermines the sense of community, social norms, a country's culture and pride, can, from this perspective, be viewed as a violation of ethical principles.

\section{INDIVIDUAL AND INSTITUTIONAL RESPONSIBILITY}

The thesis that I have advanced so far is that policies toward and within developing countries can be looked at from an ethical perspective, in terms of how they comport

${ }^{25}$ See A. Hussain, N. Stern, and J.E. Stiglitz. 2000. "Chinese Reforms from a Comparative Perspective." In Incentives, Organization, and Public Economics: Papers in Honour of Sir James Mirrlees, edited by Peter J. Hammond and Gareth D. Myles, 243-277. Oxford: Oxford University Press. 
with basic precepts of moral behavior; and so too can the behavior of those who are called on to provide economic advice to developing countries. In these terms, we have seen that many of the actions undertaken by governments and recommended by outsiders, including the IMF, do not fare well. There have been large--and some might argue unnecessarily large - adverse consequences for the poor. Take for instance the full toll that the IMF's handing of the Asian crisis has had. It was not only the increase in poverty, but also that the cutbacks in social and health expenditures in, say, Thailand, exacerbated the economic downturn. And this led to an increase in the incidence of AIDS, and the poverty itself led to an increase in the trafficking of children.

In American jurisprudence, in many states, there is the principle of contributory negligence. All parties that had a role in the adverse outcome are held, in part, responsible. Similar issues arise in the realm of ethics. To be sure, the governments made the final decision about what policies were to be pursued. But the governments were often pushed to undertake the policies by the IMF, and felt that they had little room for maneuver. Here, we do not have to parse the blame. What we can say unambiguously is that the IMF and others who supported those policies - and especially those like the US Treasury who pushed those policies--bear considerable moral culpability for the outcomes.

In the Holocaust, the world also came to an understanding that those who stand idly by when they see others commit (what they view as potentially) heinous acts also bear a certain moral responsibility. The institutions in our society that are the guardians of our morals have an especial responsibility for taking up these issues. This is particularly important given the inadequacies in our system of global governance, where the voices of the poor and the voices of poor countries are barely heard, even in matters that affect their lives and livelihoods, where democratic principles are systematically ignored. The good news is that throughout the world today, there is a growing recognition of the importance of these issues. It is an opportune time for those with moral authority to raise their voices and join the chorus of the concerned.

\section{CONCLUding REMARKS}

The past half-century has shown that with growth, development is possible, but far from inevitable. It has shown too that growth with poverty reduction is possible, but it is far from easy. There are a host of ongoing policy debates about the best way to pursue poverty reduction and growth. My concern in this chapter has not been to rehearse that debate-though inevitably I have had to touch on some of the more controversial issues--but to suggest that there are dimensions of that debate that can be usefully examined from a moral dimension, from precepts concerning such values as honesty, fairness, and a concern for the poor. Some might argue that such language speaks to the heart, and not just the head. But I argue that decisions about public policies inevitably need to speak both to the heart and the head, that it is important to think deep and 
hard about the moral dimensions of our economic decisions. One can, and indeed one should, combine this kind of moral analysis with a hardheaded analysis of the consequences and risks associated with alternative policies. Indeed, the lack of such a moral demand has all too often allowed ideology to have sway-an ideology that dishonestly claims more favorable and more certain benefits than the evidence would support, an ideology that suppresses meaningful democratic discussions of alternative courses of action, and that ignores, or at least puts insufficient weight on, the adverse consequences to the poor. Thus, I see the new humanism as a complement to hard economic reasoning, not antithetical to it; and I see the two working together as holding the greatest promise for a future international economic order based on social justice. 